See discussions, stats, and author profiles for this publication at: https://www.researchgate.net/publication/232861941

\title{
The Character of Unionism
}

Article in Irish Political Studies · January 1994

DOI: 10.1080/07907189408406521

CITATIONS

20

1 author:

Colin Coulter

National University of Ireland, Maynooth

38 PUBLICATIONS 182 CITATIONS

SEE PROFILE

Some of the authors of this publication are also working on these related projects:

stigmatic shaming View project

Austerity View project
READS

65 
This article was downloaded by: [Maynooth University Library]

On: 28 November 2014, At: 03:43

Publisher: Routledge

Informa Ltd Registered in England and Wales Registered Number: 1072954 Registered office: Mortimer House, 37-41 Mortimer Street, London W1T 3J H, UK

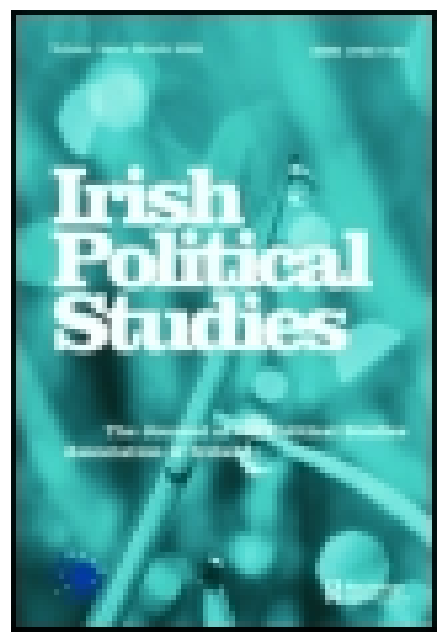

\title{
Irish Political Studies
}

Publication details, including instructions for authors and subscription information: http:// www. tandfonline.com/loi/ fips20

\section{The character of unionism}

\author{
Colin Coulter ${ }^{\mathrm{a}}$ \\ ${ }^{a}$ Department of Sociology, The Queen's University of Belfast , \\ Published online: 19 Oct 2007.
}

To cite this article: Colin Coulter (1994) The character of unionism, Irish Political Studies, 9:1, 1-24, DOI:

$10.1080 / 07907189408406521$

To link to this article: http:// dx.doi.org/ 10.1080/07907189408406521

\section{PLEASE SCROLL DOWN FOR ARTICLE}

Taylor \& Francis makes every effort to ensure the accuracy of all the information (the "Content") contained in the publications on our platform. However, Taylor \& Francis, our agents, and our licensors make no representations or warranties whatsoever as to the accuracy, completeness, or suitability for any purpose of the Content. Any opinions and views expressed in this publication are the opinions and views of the authors, and are not the views of or endorsed by Taylor \& Francis. The accuracy of the Content should not be relied upon and should be independently verified with primary sources of information. Taylor and Francis shall not be liable for any losses, actions, claims, proceedings, demands, costs, expenses, damages, and other liabilities whatsoever or howsoever caused arising directly or indirectly in connection with, in relation to or arising out of the use of the Content.

This article may be used for research, teaching, and private study purposes. Any substantial or systematic reproduction, redistribution, reselling, loan, sub-licensing, systematic supply, or distribution in any form to anyone is expressly forbidden. Terms $\&$ Conditions of access and use can be found at http:// www.tandfonline.com/page/terms-and-conditions 


\title{
THE CHARACTER OF UNIONISM
}

\author{
Colin Coulter* \\ Department of Sociology \\ The Queen's University of Belfast
}

\begin{abstract}
This paper seeks to offer a critical examination of the existing literature on unionism in Northern Ireland. It contends that recent interpretations have typically failed to grasp fully the essential diversity of the unionist mind. In particular, commentators have proved content to overlook those sécular and liberal impulses that inform the political imagination of modem unionism. The paper concludes with a brief discussion concerning how social scientists might arrive at a more faithful understanding of the character of unionism.
\end{abstract}

When the current political crisis in Northern Ireland broke in the late 1960s, nationalists immediately identified themselves as accomplished ideological combatants. Couched in the concerns and discourse of a universal ideology, the nationalist case appeared readily intelligible and unproblematic and, therefore, less worthy of social scientific enquiry (O’Dowd, 1991, pp. 163-4). Accordingly, and in spite of the insurrection against the British state sustained by elements of the nationalist community over the preceding two decades, the study of contemporary northern nationalism remains, in relative terms at least, in its infancy. ${ }^{1}$ The outbreak of the present troubles, in contrast, exposed unionists as ideologically inarticulate and introspective. The unionist community has frequently proved incapable of expounding its point of view in terms either intelligible to the outside world or consonant with the discourse of modern liberal democracy. The apparently inscrutable and anachronistic character of contemporary unionism has inevitably aroused the curiosity of those researchers drawn to the province by the ongoing political conflict (ibid). Hence, as the academic study of Northern Ireland has developed apace over the past quarter century, the focus of social scientific enquiry has tended to fall primarily upon the ideology of unionism.

Whilst the political philosophy of unionism has been afforded considerable academic attention in recent times, the various analyses that have emerged have

* I would like to thank Bob Cormack and Paul Bew for their comments and advice on an earlier version of this paper.

1. It should be acknowledged, however, that academic interest in northern Irish nationalism would appear to be currently on the rise. A number of important studies of the political beliefs and aspirations of northern nationalists have been published in the past few years. See, for instance, O'Connor (1993), Ruane and Todd (1992), and Todd (1990).

'IRISH POLITICAL STUDIES, 9, 1994, pp. 1-24 
in the main tendered a less than faithful understanding of the unionist political imagination. The study of contemporary unionism has-as Alvin Jackson (1990, p. 63) intimates-betrayed the appeal of the exotic for the social scientist. The focus of academic scrutiny has fallen principally upon those colourful figuresProtestant paramilitaries, religious fundamentalists, loyalist bandsmen and so on-who represent the extreme fringes of unionism. The preoccupation with the radical periphery of unionist politics-coupled as it is with the unreasonable assumption that the intemperate voices raised therein may be taken as representative of the unionist community as a whole-has inevitably ensured that many existing interpretations have failed to acknowledge or accommodate the sheer diversity of unionist sentiment and experience. More precisely, the apparent infatuation of many commentators with the exotica of contemporary unionism has led them to overlook those liberal and secular ideological impulses that are central to the unionist political imagination but that typically give rise to rather prosaic modes of political ambition and practice.

\section{UNIONISM AS CONDITIONAL LOYALTY}

Arguably the most influential analysis within the academic literature pertaining to unionism is that offered by David Miller (1978) in Queen's Rebels. According to Miller, the political doctrine of unionism is distinctive in that it has failed to assume the characteristics of nationalism. In an oft-quoted passage, he observes (p. 4):

... the central peculiarity in Ulster's political culture is that no community-not Britain, not the United Kingdom, not "Ulster" and certainly not Ireland-has attained for Ulster Protestants all the characteristics which a nation commonly possesses in the modern world.

As they do not relate to Britain as a nation, Ulster unionists have tended to withhold from the British state that unqualified consent that its citizens are assumed to typically offer the modern nation-state. The profoundly conditional nature of its loyalty to Britain represents for Miller $(1978$, p. 5) the ideological quintessence of unionism, reflecting an adherence to "a venerable theory of political obligation-that of the social contract thinkers" of the seventeenth century, and more specifically "the peculiar Scottish variant of contractarian thought and practice, covenanting".

The interpretation of unionism tendered by Miller is imaginative and original, and has proved of enduring appeal to many observers of northern political life. Nonetheless, the analysis embodied in Queen's Rebels remains flawed in numerous respects. The essential problem with Miller's approach lies not in his claim that the outlook of unionism is characterised by a strictly conditional loyalty to 
the British state. On the contrary, one would not have to delve far into the public statements of unionist political figures to unearth ample vindication for such a contention. The fundamental shortcoming of Miller's analysis lies rather in his identification of the contractarian aspects of unionist political thought as being aberrant and anachronistic, symptoms of a political outlook that is "anomalous in our own day" (p. 5). This identification proves to be untenable in a number of regards.

Underpinning the analysis forwarded by Miller is the assumption that the modern liberal democratic state has evolved in a manner that has effectively resolved to the satisfaction of its citizenry those vital constitutional issues that pertain to the nature and limits of government and of political obligation. As a result, it is asserted, the modern state has been able to readily evoke the unconditional loyalty of its citizens, and concern for constitutional matters has been demoted to a mere antiquarian passion. In this political climate, unionism, with its characteristic conditional loyalty and apparent fixation with the issue of the constitution, appears as an archaic and deviant ideological formation. The typifications of the modern state and of contemporary political debate upon which Miller constructs his argument are, however, distinctly erroneous. The modern liberal democratic state has, in reality, proved incapable of satisfactorily resolving the problematic matter of the relationship between government and governed. Indeed, far from having been rendered obsolete, such issues of citizenship have in fact returned to the centre stage of political debate in recent times. Hence, there are grounds for the contention that the contractarianism that pervades the ideology of unionism articulates a political concern that, rather than being outmoded, actually proves to be both modern and universal.

In more specific terms, the modern British state has persistently proved incapable of resolving the thorny issue of Northern Ireland's constitutional position within the Union. The British political establishment has offered numerous assurances that Northern Ireland will remain part of the United Kingdom until the democratic will dictates otherwise. Nevertheless, the constitutional position of the province continues to appear precarious, and has been the object of both considerable debate and armed subversion by a substantial element of the nationalist community. In view of the uncertainty that shrouds the constitutional future of Northern Ireland within the Union, it would seem both rational and inevitable that the unionist community should have remained so profoundly concerned with constitutional matters. The specific ideological character of unionism should, therefore, be regarded not so much as a reflection of unionists' adherence to an abstract and archaic political philosophy as of their habitation of a specific political environment wherein constitutional concerns remain very much a live issue.

The thesis developed in Queen's Rebels may be further challenged on the grounds that it assumes that conditional loyalty constitutes an ideological trait peculiar to unionism. In reality, of course, contractarianism is characteristic of 
the outlook of a range of political actors other than Ulster unionists. As a number of commentators (Aughey, 1991, pp. 8-9; Nairn, 1981, pp. 233-4; Rose, 1982) have observed, the British state has in fact been decidedly conditional in the loyalty it has extended to Northern Ireland. The British political establishment has, as was noted earlier, offered numerous public declarations of fidelity to the province. In practice, however, Britain has systematically endeavoured to minimise its commitment to Northern Ireland and has accordingly sought to govern the six counties not as an integral region of the state but rather as a "place apart" (Rose, 1982, p. 125). Moreover, both the British public and the British political class have proved only too willing to consider a future for Northern Ireland outside the Union. Such public ambivalence concerning the province's membership of the United Kingdom finds expression, of course, in the terms of both the Anglo-Irish Agreement and the Downing Street Declaration. The commitment of the British state to Northern Ireland emerges, therefore, as being far from absolute, and the conditional nature of its professed loyalty has had an important bearing upon the ideological persona of modern unionism. Suspecting that the intentions of Westminster regarding the Union are far from pure, the unionist community has inevitably withheld from the government its unqualified consent, as to do otherwise would place it in a singularly vulnerable position. Thus, the contractarian character of unionist ideology may be accurately conceived not as an index of unionists' antiquarian passion for the heady principles of constitutional theory, but rather as a manifestation of their well-founded suspicion that in political reality their devotion to Great Britain is unrequited. The inability of Miller to identify unionist contractarianism as an essentially rational response to a specific constitutional environment derives precisely from his failure to acknowledge that the political contract apparently so beloved of unionists actually incorporates more than one party. As a result of this particular oversight, Miller remains seemingly oblivious to the fact that the outlook of one party to such a contract, namely the Ulster unionists, cannot be viewed in isolation from that of the other party, in this case the British state.

The identification of conditional loyalty as an ideological characteristic exclusive to Ulster unionism is undermined further once we turn to consider certain salient realities of British political life. In large measure Miller founds his argument upon the assumption that, in contrast to the Northern Irish, the citizens of the rest of the United Kingdom have willingly offered their unqualified loyalty to the British state. In historical reality, however, the people of Britain have proved appreciably less politically docile than Miller would appear to assume. British history is littered with incidents of political agitation and popular unrest. The recent campaign of protest and civil disobedience in opposition to the poll tax is merely the latest in a sequence of events that illustrate the willingness of the British people to challenge the authority of the government when it offends the democratic will. The conditional loyalty offered by unionists to the British state 
does not, therefore, identify them as politically "different". On the contrary, contractarianism in fact represents an ideological trait that northern unionists share with their fellow citizens of the United Kingdom.

The single most debilitating aspect of the analysis offered in Queen's Rebels is that in defining unionists' conditional loyalty as unusual and outmoded Miller makes the implicit assumption of the existence of another form of political allegiance, presumably of an unconditional kind, that is more rational and modern. However, as Arthur Aughey (1989, p. 23; 1991, p. 6) notes, in practice no such mode of political obligation actually exists. All modern political interests, he persuasively contends, set limits to the allegiance that they extend to the state. Moreover, it is thoroughly rational that they do so. Any people that offered its unqualified loyalty to the state would in effect commit itself to a form of political serfdom. Thus, once again we are drawn to the conclusion that the conditional nature of unionists' loyalty represents not an ideological foible but a commitment to a philosophy of political obligation that is both rational and modern.

One final criticism of the conditional loyalty thesis may be proffered. Miller would appear to argue that the substantive basis of unionism's ideological and political identity derives from unionists' adherence to contractarian principles. This contention proves to be fallacious. The commitment of unionists to the Union is not motivated by an appetite for abstract political principle but rather by the more prosaic concerns of ethnic self-image and economic self-interest. Given that they live in a climate of constitutional uncertainty, unionists' political aspirations have inevitably been couched in terms that are distinctively contractarian. In other words, the contractarianism that pervades unionism represents not its ideological substance, but rather its political form. To a large extent the misrepresentation of unionism offered by Miller stems from his inability to recognise this elementary but vital distinction.

The interpretation of unionism embodied in Miller's Queen's Rebels emerges, therefore, as flawed. Despite its evident shortcomings, however, Miller's analysis has proved enduringly persuasive for observers of northern political life. In particular, the notion of conditional loyalty has proved appealing to authors hostile to the unionist project. J. J. Lee $(1989$, p. 14), for example, highlights the contractarian character of unionism as part of a systematic endeavour to denounce unionism as a squalid and self-serving ideology. The conditional loyalty that unionism offers the British state is interpreted by Lee as indicating that unionists are in fact ultimately loyal only to themselves. Whilst the explanation of the appeal of the conditional loyalty thesis to those observers hostile to unionism is obvious enough, the wide currency that the notion has enjoyed within the broader academic literature is less readily intelligible. In view of its manifold deficiencies, the fact that a political commentator as usually discerning as Padraig O'Malley (1983, pp. 150, 187) should choose to rehearse so uncritically the conditional loyalty thesis is difficult to comprehend. 


\section{UNIONISM AS PROTESTANTISM}

The role played by religion in the ongoing political unrest in Northern Ireland has been the substance of considerable academic debate. As Arthur Aughey (1989, p. 3) notes, there has been a marked propensity among political commentators to characterise the conflict in the province as not being essentially religious. Authors such as Michael MacDonald (1986), Desmond Bell (1990, p. 64) and Geoffrey Bell (1976, p. 13) have all adopted the position that the divergent religious affiliations existent within the province are not the cause of the conflict but rather mere ethnic signifiers of more salient divisions rooted in the more material realm of economic interest and political aspiration. In recent times, however, a body of work has emerged to challenge the orthodox view that religious sentiment per se exercises little influence over the political affairs of Northern Ireland (Hickey 1984). This approach is identified primarily with the writings of Steve Bruce (1986a, 1986b; Bruce and Wallis, 1985; Wallis et al, 1986) on the religiopolitical phenomenon of Paisleyism.

In his examination of contemporary unionism, Bruce (1986a, p. 258) adopts a point of departure that is similar to that employed by Miller. The political conflict in Northern Ireland, he asserts, involves a fundamental asymmetry as it represents a contest between a nation on one hand and an ethnic group on the other. The national identity assumed by northern Catholics is sufficiently secure to enable it to transcend its foundations in religious sentiment. As a result, contemporary nationalism has assumed the guise of a modern and secular political ideology. Ulster Protestants, in contrast, have failed to constitute themselves as a nation, and are best understood as representing an exclusive ethnic grouping. The relatively insecure status of unionists as an ethnic community has ensured that unionism as an ideology has proved unable to dispense with religious sentiment. Faced with a seemingly hostile political environment, unionists are perennially drawn to the tenets of evangelical Protestantism as these represent the only coherent set of beliefs that furnish unionists with a sense of political identity and the reassurance that they will be able to avoid incorporation into a hostile Catholic state (1986a, p. 264). Protestantism, therefore, does not merely exercise an influence over unionism, but rather constitutes its very essence. Moreover, Bruce contends that the appeal of evangelical Protestantism is not restricted solely to the religiously devout. On the contrary, even formally secular unionists are attracted to evangelicalism as it represents a discourse that they have "heard before, both often enough, and in such circumstances, as to instil a strong respect" (Bruce, 1986a, p. 263).

This analysis represents a distinctive and valuable contribution to the heated debate on the nature of unionism. The principal virtue of Bruce's approach derives from its acknowledgement of the influence of religious values per se on the unionist outlook. In so doing, it offers a necessary challenge to the prevailing 
analytical orthodoxy that has proved content to idly dismiss the influence of idealistic formations like religion on the Northern Ireland conflict in pursuit of monocausal materialist interpretations. Nevertheless, the evaluation of unionism tendered in Bruce's work proves to be misconceived in a number of regards. Firstly, Bruce offers the proposition that modern Irish nationalism constitutes an essentially secular political philosophy. Such an interpretation, however, fails to convince. Rather than transcending religious belief, Irish nationalism has in fact clearly borne the inscription of Catholicism. The nature of the social and political order constructed in the Republic of Ireland since its foundation stands as an indelible testament to the influence that Catholic religious sentiment has exercised over modern Irish nationalism. In this light, Bruce would appear fundamentally mistaken in his assumption that the impact of religious belief upon Irish political life has been restricted to the ideological sphere of unionism.

A second and more telling criticism that may be levelled at Bruce's approach is that it fails to grasp the genuinely diverse and complex character of unionism. Bruce contends that the evangelical Protestantism given voice in Paisleyism represents the quintessence of unionist ideology. However, such a contention is premised upon the "reductionist fallacy" that there must exist within unionism "a true 'core' which is revealed when all incidentals are swept away" (Aughey, 1989, p. 7). In reality, unionism does not possess a single essence, but rather exists as a complex formation that accommodates a number of divergent and contradictory ideological impulses and political interests sharing little in common save for a commitment to the Union itself. The ideological persona of unionism is shaped by philosophical currents that are variously liberal and reactionary, secular and sectarian. The secular counsel of the liberal tradition that exists within unionism- a tradition inherited by diverse contemporary figures who include Arthur Aughey, Laurence Kennedy, Robert McCartney, the McGimpsey brothers, those academics who operate under the nom de guerre of the Cadogan Group (1992) as well as those intellectuals who have their ideological centre of gravity in the old British and Irish Communist Organisation (B\&ICO) ${ }^{2}$-has ensured that the influence exercised by the political teachings of Ian Paisley over northern unionists, although evidently profound, has remained strictly partial. Whilst Paisleyism may be identified as an authentically unionist voice, it cannot, therefore, be assumed to define unionism in its entirety. For every unionist who votes for Paisley in the European Parliament elections there is at least another who does not; for every unionist who regards Paisley as the doughty prophet who has single-handedly defended the Union in the face of English perfidy, there is at least another who looks upon him as the individual most responsible for alienat-

2. It should be noted, however, that the remnants of the B\&ICO have recently and rapidly diverged from a unionist position. Recent editions of the B\&ICO journal.The Northern Star reveal a greater tolerance of the prospect of a united Ireland and have included calls for the Irish Labour Party to organise in the six counties. 
ing the British public and political class; and for every Protestant who embraces Paisleyism as the political expression of the one true faith, there is at least another who denounces it as the vulgar voice of parochial populism. Hence, for all its obvious significance the religio-political ideology of Paisleyism cannot be conceived as defining the essence of unionism. By assuming that it can, Steve Bruce effectively ignores the complex diversity of unionist thought to offer an interpretation of unionism that rarely rises above the level of caricature. More specifically, Bruce conspires to overlook those liberal and secular ideological impulses that inform the unionist outlook, but that are inconvenient to the thrust of his analysis. In so doing, he falls prey to an analytical failing common to many interpretations of unionism (Moxon-Browne, 1983, pp. 89-98).

Thirdly, Bruce may be challenged on the grounds that he misinterprets the precise nature of the appeal of Paisleyism for many of its adherents. Bruce adopts the line that the appeal of Paisleyism derives specifically from its religious content; that the form and substance of Paisley's discourse resonate with a particular Protestant sensibility. However, it emerges that in practice many unionists are drawn to Paisleyism for reasons that are profoundly secular. Evidence to support this contention is provided by Desmond Bell's research among young loyalist bandsmen. Bell (1990, p. 164) records that many of the bandsmen were strongly attracted to the particular brand of evangelical Protestantism expounded by Paisley's Free Presbyterian Church. The appeal of Paisleyism was, however, primarily political rather than religious, as a number of the youngsters expressed strong reservations concerning the religious fundamentalism that pervades the ideology. The loyalist bandsmen, Bell concludes, were drawn to the evangelical Protestantism articulated by Paisley for reasons that appear "secular rather than sacred, involving some sort of a search for political answers rather than for spiritual 'uplift' "'. Thus, whilst its religious credentials can scarceiy be denied, Paisleyism simultaneously operates as a distinctly temporal ideology. It is this latter element of its complex ideological persona that explains the appeal that Paisleyism exercises for many secular unionists, not, as Bruce would have us believe, the existence within the unionist community of a universal, albeit often unacknowledged, regard for the tenets of evangelical Protestantism.

\section{UNIONISM AND NATIONALISM}

The contrasting analyses furnished by Miller and Bruce share, therefore, the common assumption that unionism is ideologically distinct in having failed to assume the guise of nationalism. This characterisation represents a recurrent theme within the substantial literature devoted to unionism. It informs, for example, the thesis developed by Tom Nairn in his resonant account of the "Break-Up of Britain". Nairn (1981, p. 236) asserts that the Ulster unionist community is 
untypical of embattled societies insofar as it has proved unable to fashion for itself a distinctive national identity. Northern unionists have tended instead towards the ideological surrogates of fundamentalist Protestantism and a crude imperialism that he terms variously "Britishism" and "Union Jackery" (ibid, pp. 241-2). The essentially retarded nature of unionists' nationality, Nairn (ibid, p. 240) contends, constitutes the fundamental cause of the political conflict in Northern Ireland. It represents " $a$ 'mad' variable which falsifies every reasonable strategy of escape" from the ongoing political impasse. Accordingly, Nairn argues, the problems that bedevil northern society will be resolved only by the emergence and evolution of Ulster nationalism, an ideological development that constitutes a necessary, though potentially perilous, step along the path of political modernisation.

Unionism is further identified as an ideological formation distinct from nationalism in the research of Desmond Bell $(1987 ; 1990)$ alluded to earlier. According to Bell (1990, pp. 15-20), unionism invokes as its "imagined community" not the nation but rather an exclusive ethno-religious grouping: "the Protestant people". The imagined ethnic community conjured up by unionism is, Bell contends (p. 20), represented and renewed in the ritualised and sectarian practices of the Orange marching season. Thus, the seemingly mindless rites of populist unionism actually represent an "embodied ideology ... at work". Over the period of the troubles, however, the sense of community that forms the ideological foundation of unionism has been undermined by salient processes of social, economic and political change: economic decline in league with social democratic reform of the labour market has eroded much of the material privilege of the Protestant working class; urban redevelopment has uprooted many established loyalist communities; and the past quarter century has been marked by incessant political crises to which unionists have proved incapable of responding in a coherent or articulate manner (Bell, 1990, pp. 21-2). The manifold problems facing the unionist community in modern times have especially afflicted young Protestants, who have encountered mounting levels of unemployment. The experience of social and economic marginalisation has not, however, undermined the appeal of loyalism among Protestant youths. On the contrary, the young unemployed have become increasingly instrumental in the organisation of the ritual practices of the marching season that are assumed to embody unionism. Bell (1990, p. 210) interprets this increased participation in the ritual practices of Orange populism as an endeavour to reconstruct that "distinctively Protestant sense of community" that forms the ideological fulcrum of unionism but that has been undermined by recent patterns of social and political change. It represents, in other words, an attempt by the increasingly economically marginal Protestant young to resolve by ideological or symbolic means the very real contradictions faced both by themselves and by their parental political culture. 
Whilst by no means entirely without worth, the interpretations of unionism developed by Nairn and Bell display a number of shortcomings that render them unsatisfactory. Nairn, for example, seeks to depict unionism as exceptional in its failure to fashion an unambiguous national identity. In reality, however, the people of every region of the modern British state have exhibited-albeit in admittedly less dramatic fashion than the unionist community-a fundamental ambiguity in how they define themselves in terms of nationality. Viewed in the context of the United Kingdom, therefore, unionism appears less exceptional than has been conventionally assumed. This interpretation has been endorsed recently by Graham Walker (1992) in an article that despite its brevity stands as one of the most satisfying interpretations of unionism. Walker (p. 71) observes thus:

It is, to me as a Scot, quite astonishing how often commentators on Ulster Unionists view their ambiguous sense of national identity as an anachronistic anomaly. In the context of the UK as a whole, national identity is a deeply ambiguous and sometimes multi-layered phenomenon. The Scots at present may be in the process of clarifying their Scottishness at the expense of concepts of "Britishness", but it will be no straightforward task and it will take nothing away from the power which a dual sense of national identity has exercised there up until now.

In their writings Nairn and Bell both offer the view that the failure of unionism to assume the guise of a nationalism has ensured that it represents a singularly regressive ideological formation, one characterised by a reactionary imperialism and the crude sectarianism of Orange populism respectively. This interpretation apparently rests upon two distinct assumptions that should be vigorously contested. Nairn and Bell would seem to assume, firstly, that the emergence of a vibrant nationalist sentiment among Ulster unionists would herald an era of political progress in Northern Ireland. The faith that the authors seemingly place in the progressive status of Ulster nationalism proves, however, to be misjudged. The evolution of Northern Ireland has been blighted by an enduring sectarian enmity sedimented in resilient patterns of social relations and residential segregation. Given the province's miserable history of communal division, there would seem little prospect that an Ulster nationalism could acquire the form of a secular and inclusive political philosophy. On the contrary, the "imagined community" formulated by Ulster nationalists would in all probability be populated exclusively by northern Protestants. The nationalist sentiment to which unionists would offer expression would, in other words, assume the guise of what Anthony Smith (1993) has termed ethnic nationalism. Thus, the emergence of a vibrant Ulster nationalism would not signal the ideological rejuvenation of northern unionism-as Nairn and Bell would appear to suggest - but rather chart the further descent of the unionist community into the mire of sectarianism.

The essentially regressive character of Ulster nationalism would be largely ensured by the specific events that would prefigure its emergence and growth. The prospect of an independent Ulster has exercised remarkably little appeal 
among the ranks of the unionist community. The instrumental and affective bonds that conjoin northern unionists to the rest of the United Kingdom have proved sufficiently powerful to dissuade contemplation of political life beyond the Union. The only political scenario that could be realistically expected to convince a substantial body of unionists of the virtues of independence would be were the British state to endeavour to manoeuvre the province into a united Ireland. The decision to construct an autonomous six-county state would, therefore, be one taken reluctantly by an increasingly embattled and embittered unionist people. Possessed of such a mindset, it would be unlikely that the architects of an independent Ulster would prove able to summon either the goodwill or the vision to establish a viable society founded upon the inclusive ideal of a secular pluralism.

The manifold iniquities of an independent Ulster would be merely amplified by the material conditions that would obtain therein. The constitutional option of independence enjoys the support of none of the principal external players in the Northern Ireland conflict. The establishment of the province as a sovereign state would, therefore, inevitably invoke the ire of both London and the wider international community. Deprived of external economic assistance-not to mention the currently huge subvention from Westminster-the six counties would inexorably slide into an austerity indexed by endemic unemployment and soaring emigration. In such a climate of fierce competition for increasingly scarce material resources, regard for liberal notions of social justice would quickly evaporate and the apparatuses of the state would come to be harnessed in pursuit of the particular interests of the ethnic Protestant community. Hence, the emergence of nationalist sentiment among northern unionists would scarcely-as Nairn and Bell would have us believe-herald the dawn of political progress in the six counties. On the contrary, a vibrant Ulster nationalism would in time merely come to constitute an indispensable ideological prop of a restored "Protestant state for a Protestant people".

The contention of Nairn and Bell that the inability of unionism to assume the form of a bona fide nationalism has condemned it to the status of a thoroughly reactionary political philosophy apparently rests upon a second assumptionimplicit in Bell's (1990, p. 140) account but explicit in that tendered by Nairn (1981, p. 241)-that nationalism per se represents a relatively progressive ideological construct. This benign interpretation of nationalism, fails, however, to square with the realities of contemporary political life. The 1990s have borne witness to political horrors whose principal authors have been a resurgent ethnic nationalism and its bastard ideological sibling of fascism (Anderson 1992; Ascherson 1991, 1993). Evaluated from the vantage point of the present decade, the depiction of nationalism as an essentially progressive ideological formation is, therefore, difficult to swallow. Viewed in this particular context, moreover, the 
ambiguity of unionists' national identity begins to appear less problematic than has frequently been assumed.

The interpretations tendered by Nairn and Bell may be further challenged on the grounds that neither author manages to come to terms with the complex diversity of unionist thought. Nairn and Bell seek to characterise unionism in terms of anachronistic imperialism and vulgar sectarianism respectively. Whilst these ideological traits undoubtedly represent important impulses shaping the unionist mind, they should not be assumed to identify unionism in its entirety. Within the diverse environs of the unionist political imagination, there also exist ideological currents that are liberal, secular and progressive. The existence of an essentially enlightened tradition of unionist thought has found expression through the beliefs and practices of a range of political actors, most notably those unionists who orchestrated the opposition to the second Home Rule Bill (Gibbon, 1975, pp. 132-9), who struggled to build an independent labour movement during the Stormont years in spite of the manifold obstacles created by the terms of the partition settlement (Walker, 1985, pp. 38, 87, 216-17), who eschewed the demands of communal interest to campaign for equitable civil rights in the sixties, who founded the centrist Alliance Party in the aftermath of the eruption of the current political unrest and who, most recently, have endeavoured in the face of considerable resistance to persuade the British Labour Party to organise throughout the six counties. The analyses offered by Nairn and Bell conspire to overlook these relatively progressive aspects of the complex ideological persona of unionism. As a consequence, both authors proffer typifications of unionism that may be dismissed as unacceptably crude pejorative stereotypes.

\section{UNIONISM AS REACTION}

Within the substantial literature that pertains to unionism, there exist a number of studies that may be identified as sympathetic to the unionist project (Aughey 1989; Bruce 1986a; Nelson 1984; Roche and Barton 1991; Wilson 1989). In the main, however, social researchers and political commentators have tended to offer accounts of unionism that are distinctly critical and unflattering. This analytical trend finds reflection in a number of works. In his book The Protestants of Ulster, the northern Protestant Geoffrey Bell (1976) issues a blistering attack upon unionism. For Bell (p. 9), unionism represents the "voice of unreason, the voice of illogicality". In ideological terms, he insists (1976, pp. 48-63), unionism is singularly reactionary, characterised by sectarianism, supremacism, misogyny ${ }^{3}$

3. The charge of sexual conservatism has been levelled at unionism by a number of cornmentators. In his book Disillusioned Decades, Tim Pat Coogan (1987, p. 185), for instance, claims that unionism is marked by an "anti-ferninism" that bespeaks a "repressed homosexuality". The accusation that unionists are reactionary with regard to sexual matters is aiso issued by Gerardine 
even. The supremacism identified by Bell as central to the outlook of unionism is also alluded to by Lee (1989) in his recent influential though tendentious account of modern Irish history. Without offering appropriate evidence to substantiate his case, ${ }^{4}$ Lee (pp. 2-14) contends that the sense of superiority that pervades the unionist mind has typically expressed itself in the form of racism. The Ulster Protestant community, he asserts (p. 4), represents a "Herrenvolk democracy" which, like all settler societies, relates to the native Catholic population in terms of a racial stereotype. A further critical consideration of unionism may be found in the Field Day pamphlet written by Terence Brown, himself an Ulster Protestant. Brown (1985, p. 8) asserts that the historical imagination of unionism is essentially "impoverished". As it lacks the "complex, rich, emotional identity" of nationalism, the unionist mind is "bound to comprehend much less of the human condition". The apparent philosophical dereliction of unionism is a theme taken up by the sociologist Liam O'Dowd. According to O'Dowd (1991, p. 153), one of the fundamental reasons for the lack of meaningful political dialogue in Northern Ireland has been the historical inability of unionist political culture to spawn an intellectual class. The apparent intellectual impoverishment of the unionist community, moreover, is compounded by the fact that unionism has proved incapable of expressing itself in terms of a broader and more modern political philosophy "such as liberal democracy, socialism or nationalism" (ibid, p. 165). The impression of unionism created by Liam O'Dowd, therefore, is one of an ideology that is irretrievably retarded and pre-modern.

The characterisation of unionism as singularly and uniformly reactionary should be vigorously contested. The depiction of northern unionists as incorrigibly supremacist tendered by Bell and Lee offers an understanding of the unionist mind that proves merely partial. The unionist community has undoubtedly exhibited an historical proclivity towards triumphalism. The political outlook and conduct of modern generations of Ulster Protestants have also, however, been informed by an enduring sense of insecurity and inferiority (Nelson, 1984; Walker, 1992, p. 69). The indices of these feelings of subordination are legion: the chafing embarrassment that has arisen out of the painfully evident inability of unionist politicians to combat the guile of an impressively articulate generation of young republicans; the disquiet occasioned by the failure of northern Protestants to construct for themselves an ethnic persona as vibrant or cogent as that formulated by an increasingly culturally confident nationalist community; above all, the pervasive and abiding conviction that the tide of modern Irish history has shifted irreversibly in a direction that will prove ultimately inimical to the Union. The

Meaney (1991, p. 10) who asserts: "It is not just nationalist Ireland which exhibits the traits of sexual conservatism and social stagnation. Unionism is if anything more insecure and equally prey to the sexualisation of political identity, even if this takes different forms. The fundamentalist streak in northem Protestantism is as hostile to feminism as is Catholicism".

4. For a critical evaluation of Lee's treatment of Ulster unionism, see Bew (1990). 
sense of powerlessness and beleaguerment shared by a substantial section of unionist opinion has inevitably served to corrupt and debilitate unionism as an ideological construct. The political fatalism and pessimism characteristic of many northern Protestants have typically sponsored a sullen, mindless intransigence that has deprived unionism of both purpose and influence. In this light, it would seem plausible to suggest that it is Ulster unionists' feelings of political and cultural impotence-rather than, as authors such as Bell and Lee would have us believe, their propensity towards a swaggering supremacism-that constitute the principal author of the reaction that undoubtedly infects much of the unionist political imagination.

The portrayal of unionism as philosophically derelict furnished by Brown and O'Dowd should also be heavily qualified. The unionist community in the north of Ireland has admittedly for much of this century exhibited little facility or appetite for sustained ideological rumination. The terms of the partition settlement effectively relieved northern unionists of the necessity to engage in ideological combat. The possession of state power under Stormont enabled unionists to pursue their political ends through means of force rather than force of argument. Much of the ideological indolence that has blighted Ulster unionism historically has of course survived the vicissitudes of the past quarter of a century. The era of direct rule has, on the other hand, impressed upon the minds of many unionists the need to reflect upon their political identity and to communicate their beliefs to a wider audience. The advent of the Anglo-Irish Agreement in particular served to disturb elements within the unionist fold from their ideological slumber. The charged atmosphere created by the Hillsborough Accord revealed the existence of a small but gifted coterie of broadly unionist intellectuals who had gravitated toward the demand that the British political parties organise in Northern Ireland. The ideologues of electoral integration have proffered a lucid and spirited defence of the Union that has skilfully plundered the lexicon of modern liberal democracy. One should, of course, exercise caution not to overstate the importance and influence of figures such as Arthur Aughey, Brendan Clifford (1985, 1986a, 1986b, 1987a, 1987b, 1989), Arthur Green $(1988,1990,1991,1992)$ and Robert McCartney $(1985,1986 \mathrm{a}, 1986 \mathrm{~b}, 1992)$. Nevertheless, it remains reasonable perhaps to acknowledge the writings of these individuals as emblematic of a potentially significant-though distinctly fragile-intellectual renaissance within the unionist community, one to which political commentators such as O'Dowd remain seemingly oblivious.

The diverse analyses forwarded by those critics who have sought to depict and denounce unionism as the ideological embodiment of political reaction share at least one significant shortcoming in common. There can be little doubt that the various unsavoury characteristics identified by the likes of Bell, Brown, Lee and O'Dowd are amply represented within the broad ideological environs of unionism. It would scarcely strain the ingenuity of the social researcher to unearth evi- 
dence of sectarianism, supremacism and intellectual impoverishment among the unionist community. However, it must be acknowledged that unionism constitutes a complex and variegated ideology that also accommodates political impulses that are modern, secular and progressive. In recent times the essentially enlightened tradition of unionist thought has been borne principally by those intellectuals who have congregated beneath the standard of electoral integration. The interpretations furnished by figures such as Bell and others complacently overlook those progressive impulses that inform the unionist mind. In so doing, these authors in effect seek to write out of existence an entire swathe of unionist sentiment and experience that is significant but inconvenient for their analytical or polemical purposes.

\section{UNIONISM AS A LIBERAL POLITICAL IDEAL}

The past few years have witnessed the publication of a number of works favourably disposed towards the unionist case. The most cogent consideration of unionism from a unionist perspective is undoubtedly that provided in the writings of the neo-liberal intellectual Arthur Aughey (1989; 1990; 1991). The central premise of Aughey's argument is that "unionism is defensible in terms that are rational and coherent, and that its compatibility with contemporary political notions has been consistently neglected" (1989, pp. 1-2). In a wide-ranging and impressive demolition of the relevant literature, Aughey (ibid, pp. 1-29) contends that existing accounts of unionism have failed to grasp its genuine nature as they have considered it in terms of concepts and analytical frameworks more appropriate to the study of nationalism. Unionism, he argues, cannot be conceived in terms of exclusive substantive identities such as nationality or ethnicity. Rather, the essence of unionism is the commitment and aspiration to live in a British state that embodies the modern values of liberal pluralism. The appropriate concepts for understanding unionism, therefore, are not nationalism and the nation, but rather citizenship and the state. As unionism is motivated by the ideal of citizenship rather than a sense of national identity, it constitutes an ideology capable of accommodating Catholics and Protestants alike (ibid, p. 19). Thus, for Aughey, unionism represents a liberal and inclusive ideological formation that is more appropriate to conditions of the modern multinational state than the exclusive principle of nationalism.

The line of analysis developed by Aughey constitutes a lucid exposition and defence of the unionist case, couched in terms that are consonant with the concepts and concerns of modern political debate. The rational and articulate vision of unionism that he tenders marks a radical departure from the discourse of modern Unionism, which has typically been characterised by cant, introversion and intellectual impoverishment. Indeed, the cogent polemic of Under Siege so 
impressed Dennis Kennedy (1990) that he was moved to proclaim that in Arthur Aughey unionism had at last discovered a "positive voice". Nevertheless, the portrayal of unionism furnished by Aughey proves ill-considered in a number of respects. The essential shortcoming of Aughey's account derives from his provision of an abstract and idealised characterisation of unionism that fails to take on board the realities of unionist motivation and political practice. While the political aspirations of many unionists may very well stem from their adherence to abstract ideals of citizenship, they are also motivated by substantive identities such as nationality and ethnicity. Anyone who has ever witnessed an Orange parade or engaged flesh and blood unionists in conversation regarding their political beliefs could hardly draw a different conclusion. Furthermore, it is amply evident that in political practice unionism has frequently exhibited characteristics that are the very antitheses of those ascribed to it by Aughey. Whilst Aughey (1989, p. $28 ; 1991$, p. 15) acknowledges the unsavoury realities of unionist political conduct, he contends that they do not alter the "true" nature of unionism as a liberal and secular ideological formation. Such a contention is, however, unacceptable on epistemological grounds. If one accepts that the political reality of unionism has no bearing upon its ideological character, then the discussion of the nature of unionism comes to be located in a realm of philosophical speculation wherein no proposition can be satisfactorily affirmed or refuted. In such a context, any interpretation of unionism is plausible, at least in principle, as none can be authenticated through reference to empirical reality. The character of unionism could be interpreted as plausibly in relation to the movement of the planets, to employ a suitably outlandish illustration, as in terms of the ideal of citizenship. Thus, we are drawn to the conclusion that any adequate interpretation of unionism must be grounded in an acknowledgement of certain salient political realities. To do otherwise, as is the case in Aughey's approach, is to offer a characterisation of unionism of dubious epistemological worth.

The abstract and idealised interpretation of unionism provided by Arthur Aughey is indicative of an inconsistency in his approach that bespeaks an ideological prejudice. As intimated previously, Aughey's conception of unionism is untethered by historical or contemporary political realities. Whilst Aughey acknowledges that in practice unionism has frequently been sectarian and authoritarian, he dismisses such traits as a corruption of the genuine ideological persona of unionism. However, no such lenience is displayed when nationalism comes under examination. Aughey (1989, pp. 11-12) offers the reasonable contention that the claims of Irish nationalism should be considered in terms of the concrete expressions that it has assumed in practice. In other words, Irish nationalism should be examined in light of the specific character and development of the Republic of Ireland. For Aughey, such an examination exposes nationalism as authoritarian and confessional, and therefore as offensive to the unionist political conscience. Thus, Aughey employs different criteria by which to examine union- 
ism and nationalism respectively. Unionism is approached as an abstract political philosophy conveniently untainted by the actualities of political practice. Nationalism, in contrast, is depicted as being defined by the specific character of the southern state. This analytical inconsistency intimates an unjustified political prejudice on Aughey's part that none of his lucid polemic can obscure.

One further fundamental shortcoming of the interpretation of unionism tendered by Arthur Aughey may be highlighted. In his survey of prominent theoretical approaches to unionism, Aughey $(1989$, p. 7) takes issue with Bruce's argument that evangelical Protestantism constitutes the essence of unionirm. This contention, Aughey asserts, is premised upon the erroneous assumption that there exists within unionism a "true core" of belief. In seeking to portray Protestant fundamentalism as the ideological fulcrum of unionism, Bruce overlooks other important strands of unionist thought and thereby offers a depiction of unionism that is essentially a caricature. Aughey's critique of the reductionist idealism in the work of Steve Bruce is thoroughly justified. Ironically, however, Aughey's own account of unionism falls prey to the same analytical shortcoming of which he accuses Bruce. Aughey also clearly identifies unionism as possessing a definable essence, in this case a liberal, secular political conscience. In this particular respect, Aughey's typification of the unionist imagination is no more adequate than that proffered by Bruce. Unionism stands as a heterogeneous ideology and any account that neglects such diversity in pursuit of an illusory essence must be dismissed as inadequate.

\section{TWO TRADITIONS IN UNIONIST POLITICAL CULTURE}

Social scientists and political commentators have-as we have witnessed already-displayed a marked propensity to deny the essential diversity of northern unionism. There have, of course, been a number of honourable exceptions to this broad analytical trend. Authors such as Rose (1971), Bew, Gibbon and Patterson (1979) and Wright (1973) have founded their analyses of unionism upon the recognition of the existence of divergent ideological concerns and political interests within the unionist fold. The political commentator who can be identified as most successfully having come to terms with the ideological diversity of the unionist imagination is arguably Jennifer Todd $(1987 ; 1988)$. Todd identifies numerous ideological strands within unionism, two of which she teases out for systematic analysis and which she terms the "Ulster Loyalist" and "Ulster British" traditions respectively. The Ulster Loyalist tradition exhibits ideological traits similar to those that political observers have typically ascribed to unionism as a whole. Ulster Loyalists, Todd $(1987$, p. 3$)$ argues, invoke as their primary imagined community that formed exclusively by northern Protestants, and possess only a secondary and conditional identification with Britain. The boundaries 
and unity of the imagined Protestant community are maintained and reproduced through the "potentially dominatory rituals" of the marching season. The ideological substance of Ulster Loyalism, Todd contends, derives from a fundamentalist evangelical religious sentiment. The contrast with the "Ulster British" ideological tradition could scarcely be more stark. The Ulster British tend to identify with Britain as their primary imagined community and display merely a secondary regional affiliation with Northern Ireland (ibid, p. 11). The identification of the Ulster British with Britain stems directly from the fact that the typical patterns of opportunity or "life-paths" that they experience tend to be structured by the British state and economy. In ideological terms. the Ulster British outlook involves adherence to those values of liberal pluralism that are assumed to be embodied in the political culture of the British state.

The work of Jennifer Todd clearly represents one of the most lucid and persuasive contributions to the debate on the character of unionism. In particular, Todd is to be commended for acknowledging the role played both by ideas and by material processes in moulding the outlook of unionism. By so doing, she manages to work a middle furrow between the poles of a naive idealism and a crude materialism around which many interpretations of unionism have tended to gravitate. Her work does, nevertheless, exhibit a number of relatively minor analytical blemishes. Specifically, certain aspects of the consideration that Todd offers to that liberal mode of unionist sentiment that she terms "Ulster British" are open to question. Todd asserts (1987, p. 11), for example, that the ideological disposition of the Ulster British is equally consistent with a political aspiration either to devolution or integration. Such an assertion emerges, however, as distinctly questionable. The Ulster British regard themselves as part of an historic ethnic community that incorporates the United Kingdom as a whole and identify with the secular values and institutions of the British polity. Accordingly, it would appear rational that, ceteris paribus, they should tend towards integration, which would allow them to participate in the politics of the state, rather than devolution, which historically has distanced the province from the political life of the United Kingdom.

One might also take issue with the particular course of ideological development that Jennifer Todd maps out for the Ulster British. Todd acknowledges that the form and conduct of British government policy under direct rule have engendered disquiet among the ranks of the Ulster British. The signing of the Hillsborough Accord in particular encouraged many Ulster Britons to re-evaluate their sense of identity and constitutional aspirations. Whilst conceding that the outcome of this process of ontological and political speculation remains unclear, Todd (1987, p, 22) implies a likelihood that the Ulster British will be drawn towards an ethnic identity that affords parity to feelings of Irishness. In reality, however, this has not happened. The advent of the Hillsborough Accord has persuaded remarkably few northern Protestants to dispense with Britishness as their 
principal mode of ethnic being. Indeed, on the contrary, one of the most eyecatching ideological developments in the days after Hillsborough was the emergence as an influential political philosophy of electoral integrationism, which gave voice to a distinctly vibrant and unequivocal sense of Britishness.

The response of the Ulster British to the Anglo-Irish Agreement reveals the abiding contradictions of public policy under direct rule. The conduct of the British political establishment since the dissolution of Stormont has borne the inscription of two contrasting-and ultimately conflicting-ideologies of state; one that has shaped political developments and another that has found expression in the domain of social and economic policy. The political objectives pursued by Westminster over the past two decades have invariably reflected the perennial concern of the British state to insulate itself from the political affairs of Northern Ireland. The desire of the British state to maintain a political distance from the province has found manifestation in a succession of ill-starred attempts to formulate an internal solution to the conflict and a somewhat less than resolute commitment to the current constitutional status of the six counties. The seeming indifference of the British political class to the existence and health of the Union codified in documents such as the Anglo-Irish Agreement and, more recently, the Downing Street Declaration has inevitably moved many Ulster Britons to consider the nature of their political allegiance. While the ambition of Westminster to govern Northern Ireland as "a place apart" may have encouraged the Ulster British to reflect upon their political beliefs and interests, the conclusions to which they have been drawn by such speculation have, however, been determined primarily by the operation of another, altogether different ideology of the modern British state.

In the realm of social and economic affairs, the hand of direct rulers has been guided by a particular mode of welfarism, one long since abandoned throughout the rest of the state and amplified by the specific conditions that the war has created within the six counties. The relative benevolence of the British exchequer under direct rule has effected a radical transformation of Northern Ireland. Over the past two decades a substantial swathe of northern society has become ever more fully integrated into the social and economic life of the United Kingdom. The impact of the direct rule era has proved particularly profound upon the more affluent strata within the Protestant community - those very individuals who represent the principal constituency of the Ulster British variant of unionist ideology. In recent times many middle-class Protestants have enjoyed burgeoning wealth and have been drawn more closely than hitherto into the mainstream of British society. The response of the Ulster British to the Anglo-Irish Agreement clearly reflects the Protestant middle classes' deeply rewarding experience of direct rule. Whilst the Hillsborough Accord may have offended and disoriented those northern Protestants within the Ulster British tradition, the instrumental and cultural interests of such unionists in the longevity of direct rule has ensured that 
they have responded by seeking to underwrite rather than dismantle the Union; to affirm rather than renounce their Britishness. The relative profligacy of successive direct rule administrations, therefore, has served to wed many Ulster Britons ever more firmly to the ideal of the Union. The operation of British welfarism in the context of Northern Ireland has, in other words, contrived to frustrate the ultimate strategic ambition of the British state to disengage from the province altogether.

\section{CONCLUSION}

Unionism has been the object of sustained and varied academic enquiry over the period of the present political unrest, but the substantial literature devoted to Ulster unionism displays a range of deficiencies. Arguably the most common shortcoming among the myriad of analyses that have appeared has been a propensity to conceive of unionism in unidimensional terms, thereby ignoring the significant diversity of unionist political belief and practice. In more specific terms, many commentators have tended to overlook those broadly progressive ideological impulses that inform the outlook of unionism. They have thereby proved content-to employ a distinction frequently drawn by northern unionists themselves-to conflate unionism with Unionism. ${ }^{5}$

The shortcomings exhibited by the existing literature suggest the urgent need for a more rigorous and faithful understanding of the unionist mind. The manner in which political sociology seeks to theorise contemporary unionism must change in a number of respects. Social scientists must abandon the seemingly perennial quest for the illusory essence of unionism in order to grasp more fully the complex and variegated character of the unionist political imagination. The recognition of the essential diversity of unionism, moreover, must be located within a broader understanding of its material, institutional and political foundations. One of the principal ambitions of political sociology must be to map out the various divisions produced within the unionist fold by key variables such as class, gender and locale and to illuminate the manner in which these fissures are

5. Some explanation of the distinction being drawn between "unionism" and "Unionism" should be offered here. The term "unionism" simply denotes a political commitment to the United Kingdom. It has no ethnic or religious connotations. Hence, individuals of all ethno-religious backgrounds and none can - in principle at least-acquire the status of "unionist". The term "Unionism", in contrast, denotes not merely a constitutional aspiration but also a specific ascribed ethnoreligious identity. The status of "Unionist" can be attained only by members of the Protestant community within the province. "Unionism" offers ideological expression to the exclusive sectarian interests of northern Protestants and is actualised through the practice of the Unionist parties. The distinction between "unionism" and "Unionism" occurs with some regularity in the popular discourse of northern unionists, but features less frequently in the academic literature. It was employed most recently in a clinical examination of the Downing Street Declaration by John Wilson Foster (1994, p. 37). 
reflected and refracted at the level of ideological formation, political practice and electoral preference. Any adequate conceptual understanding of modern unionism must also be founded upon an acknowledgement of the centrality of the British state in producing and reproducing those tensions existent among the ranks of northern unionists.

Whilst clearly there remains space for grand theoretical interpretations of the unionist mind, the study of contemporary unionism would benefit from the simultaneous adoption of a rather less ambitious approach that employs a more narrow focus than has often been the case hitherto. Political sociologists should, through their research practice, endeavour to deconstruct the notion of a discrete, seamless unionist community by undertaking closely detailed examinations of specific elements therein-whether class fragments, religious denominations or particular localities. The opportunities afforded by the adoption of a less ambitious research remit should be employed in particular to consider those philosophical currents within unionism that heretofore have been largely overlooked. More specifically, social scientists should begin to explore the ideological terrain of what Alvin Jackson (1990, p. 63) has termed "suburban and constitutional" unionism; that diverse body of broadly liberal and primarily middle-class unionists whose political beliefs and ambitions have frequently - and erroneouslybeen assumed to resemble closely those that emanate from the exotica of the unionist community. The employment of a more empirically grounded and narrowly focused research strategy will considerably enhance our understanding of the ideological personae of modern unionism. The conduct of a series of detailed studies of specific fragments of the unionist community will eventually furnish a body of information on northern unionists ontologically richer and more authentic than that that exists presently. The existence of such a resource will illustrate the essential diversity of the unionist mind and thereby counsel caution to those commentators tempted to ascribe a spurious unity of belief to contemporary unionism. More importantly, perhaps, it may in time provide the foundations upon which a more elaborate and faithful theoretical understanding of unionism may be constructed.

Finally, political sociologists should approach unionism possessed not merely of a different method but of a different frame. of mind. In the past a number of observers have addressed the political philosophy of unionism in what has appeared a somewhat hostile spirit. Those authors considered earlier under the heading "Unionism as Reaction" (pp. 12-15) spring most readily to mind in this context. Social scientists are of course entitled-and indeed obliged-to offer a critical understanding of unionism. They should also, however, summon the objectivity to at least allow unionists a fair hearing. To employ a phrase briefly in vogue last year, political sociologists should in the future perhaps condemn northern unionists a little less in order to understand them a little more. 
There are, therefore, a number of measures that should be adopted to enhance the study of contemporary unionism. The formulation of a more rigorous and faithful understanding of the unionist mind along the lines tentatively sketched above will, of course, prove no easy task. The influential work of Jennifer Todd, however, has already made giant strides in that particular direction.

\section{REFERENCES}

Anderson, Benedict, 1992. "The new world disorder", New Left Review 193, pp. 4-13.

Ascherson, Neal, 1991. "Why the future waves a flag", The Independent on Sunday, 8 September.

Ascherson, Neal, 1993. "Better peaceful separation than forced tolerance", The Independent on Sunday, 16 May.

Aughey, Arthur, 1989. Under Siege: Ulster Unionism and the Anglo-Irish Agreement. Belfast: Blackstaff Press.

Aughey, Arthur, 1990. "Recent interpretations of unionism", Political Quarterly 61:2, pp. 188-99.

Aughey, Arthur, 1991, "Unionism and self-determination", pp. 1.16 in P. J. Roche and B. Barton (eds), The Northern Ireland Question: myth and reality. Aldershot: Avebury Press.

Bell, Desmond, 1987. "Acts of Union: youth sub-culture and ethnic identity amongst Protestants in Northem Ireland", British Journal of Sociology 38:2, pp. 158-83.

Bell, Desmond, 1990. Acts of Union: youth culture and sectarianism in Northerm Ireland. London: Macmillan Education.

Bell, Geoffrey, 1976. The Protestants of Ulster. London: Pluto Press.

Bew, Paul, 1990. "An iconoclastic history, yet partly it's dated", Fortnight 283, April, pp. $23-4$.

Bew, Paul, Peter Gibbon and Henry Patterson, 1979. The State in Northern Ireland: political forces and social classes. Manchester: Manchester University Press.

Brown, Terence, 1985. The Whole Protestant Community: the making of a historical myth. Derry: Field Day.

Bruce, Steve, 1986a. God Save Ulster: the religion and politics of Paisleyism. Oxford: Oxford University Press.

Bruce, Steve, 1986b. "Prods and Taigs: the sectarian divide", Fortnight 242, July, pp. 5-6.

Bruce, Steve and Roy Wallis, 1985. "Defender of a faith", The Times Higher Education Supplement, 5 July.

The Cadogan Group, 1992. Northern Limits: boundaries of the attainable in Northern Ireland politics. Belfast: The Cadogan Group.

Clifford, Brendan, 1985. Parliamentary Sovereignty and Northern Ireland: a review of the party system in the British constitution with relation to the Anglo-Irish Agreement. Belfast: Athol Books.

Clifford, Brendan, 1986a. Parliamentary Despotism: John Hume's aspiration. Belfast: Athol Books.

Clifford, Brendan, 1986b. Government without Opposition. Belfast: Athol Books.

Clifford, Brendan, 1987a. The Unionist Family. Belfast: Athol Books.

Clifford, Brendan, 1987b. The Road to Nowhere: a review of Unionist politics from $O$ 'Neill to Molyneaux and Powell. Belfast: Athol Books.

Clifford, Brendan, 1989. "The political impotence that fuels rebellion", The Independent, 22 March. 
Coogan, Tim Pat, 1987. Disillusioned Decades: Ireland 1966-87. Dublin: Gill and Macmillan.

Foster, John Wilson, 1994. "Processed peace?", Fortnight 326, March, pp. 35-7.

Gibbon, Peter, 1975. The Origins of Ulster Unionism. Manchester: Manchester University Press.

Green, Arthur, 1988. "Unionist horizons", Irish Review 4, Spring, pp. 27-32.

Green, Arthur, 1990. "Conservatism meets 'cultural traditions' ", Fortnight 280, January, pp. 31-2.

Green, Arthur, 1991. Integration for Ulster: the broader view. Belfast: The Conservative Integration Group.

Green, Arthur, 1992. "Cultural traditions: a border view", The Equal Citizen October, pp. 46.

Hickey, John, 1984. Religion and the Northern Ireland Problem. Dublin: Gill and Macmillan.

Jackson, Alvin, 1990. "Unionist history (ii)", Irish Review 8, Spring, pp. 63-9.

Kennedy, Dennis, 1990. "Unionism finds a positive voice", Fortnight 285, June, p. 25.

Lee, J. J., 1989. Ireland 1912-85: politics and society. Cambridge: Cambridge University Press.

McCartney, Robert L., 1985. Liberty and Authority in Ireland. Derry: Field Day.

McCartney, Robert L., 1986a. We Have a Vision. Belfast: Campaign for Equal Citizenship.

McCartney, Robert L., 1986b. What Must be Done: a programme for normalising politics in Northern Ireland. Belfast: Athol Books.

McCartney, Robert L., 1992. "A bad joke: voting for powerless parties in a political wasteland", Sunday Times, 22 March.

MacDonald, Michael, 1986. Children of Wrath: political violence in Northern Ireland. Cambridge: Polity.

Meaney, Gerardine, 1991. Sex and Nation: women in Irish culture and politics. Dublin: Attic Press.

Miller, David W., 1978. Queen's Rebels: Ulster loyalism in historical perspective. Dublin: Gill and Macmillan.

Moxon-Browne, Edward, 1983. Nation, Class and Creed in Northern Ireland. Aldershot: Gower.

Nairn, Tom, 1981. The Break-Up of Britain, 2nd edition. London: New Left Books.

Nelson, Sarah, 1984. Ulster's Uncertain Defenders: Protestant political, paramilitary and community groups and the Northern Ireland conflict. Belfast: Appletree Press.

O Connor, Fionnuala, 1993. In Search of a State: Catholics in Northern Ireland. Belfast: Blackstaff.

O'Dowd, Liam, 1991, "Intellectuals and political culture: a Unionist-Nationalist comparison", pp. 151-73 in Eamonn Hughes (ed.), Culture and Politics in Northern Ireland, 1960-1990. Buckingham: Open University Press.

O'Malley, Padraig, 1983. The Uncivil Wars: Ireland today. Belfast: Blackstaff Press.

Roche, Patrick J. and Brian Barton, 1991. The Northern Ireland Question: myth and reality. Aldershot: Avebury.

Rose, Richard, 1971. Governing without Consensus. London: Faber and Faber.

Rose, Richard, 1982. "Is the UK a state? Northern Ireland as a test case", pp. 100-36 in P. Madgwick and R. Rose (eds), The Territorial Dimension in UK Politics. London: Macmillan.

Ruane, Joseph and Jennifer Todd, 1992. "The social origins of nationalism in a contested region: the case of Northem Ireland", pp. 187-211 in John Coakley (ed.), The Social Origins of Nationalist Movements: the contemporary West European experience. London: Sage. 
Smith, Anthony D., 1993. "Origin of nation", The Times Higher Education Supplement, 8 January, pp. 15-16.

Todd, Jennifer, 1987. "Two traditions in Unionist political culture", Irish Political Studies 2, pp. 1-26.

Todd, Jennifer, 1988. "The limits of Britishness", The Irish Review 5, pp. 11-16.

Todd, Jennifer, 1990. "Northern Irish nationalist political culture", Irish Political Studies 5 , pp. 31-44.

Walker, Graham S., 1985. The Politics of Frustration: Harry Midgley and the failure of Labour in Northern Ireland. Manchester: Manchester University Press.

Walker, Graham S., 1992. "Old history: Protestant Ulster in Lee's Ireland", Irish Review 12, Spring/Summer, pp. 65-71.

Wallis, Roy, Steve Bruce and David Taylor, 1986. No Surrender! Paisleyism and the politics of ethnic identity in Northern Ireland. Belfast: Department of Social Studies, The Queen's University of Belfast.

Wilson, Tom, 1989. Ulster: conflict and consent. Oxford: Basil Blackwell.

Wright, Frank, 1973. "Protestant ideology and politics in Ulster", European Journal of Sociology 14, pp. 213-80. 